\title{
Peran Interaksi Simbolik dalam Perencanaan Komunikasi Pemasaran di Masa Pandemi (Studi Kasus LongTang)
}

\author{
Novi Tandriawan, Muhammad Adi Pribadi \\ novitandriawan123@gmail.com,adip@fikom.untar.ac.id \\ Fakultas Ilmu Komunikasi Universitas Tarumanagara
}

\begin{abstract}
With the existence of Covid 19, the business of growing drinks and food is hampered. This makes business people at the beverage shop experience a loss. Therefore, business people must see how to plan in doing marketing properly in order to overcome this and produce good results. Marketing communication can be done in various media. The development of technology today makes it easy and fast for people to get what they are looking for, especially for business people, this is very important and there are no longer obstacles for them to do marketing of their products. In this marketing research, symbolic interaction and communication become interrelated so that one another must work together to facilitate marketing communication. This study uses symbolic interaction theory and the concept of marketing communication. The approach used in this research is qualitative research with a case study strategy. The data was collected by using in-depth interviews, documentation and direct observation. In this study, interactions occur in longtang marketing products because of the interaction and planning of marketing communications that are able to reach consumers to buy.
\end{abstract}

Keywords: marketing communication planning, social media, symbolic interactions

\begin{abstract}
Abstrak
Dengan adanya covid 19 ini, bisnis pertumbuhan minuman dan makanan menjadi terhambat. Hal ini membuat pelaku bisnis pada kedai minuman mengalami kerugian. Maka dari itu, pelaku bisnis harus melihat bagaimana perencanaan dalam melakukan pemasaran dengan benar agar dapat mengatasi hal tersebut dan memberikan hasil yang baik. Komunikasi pemasaran dapat dilakukan dalam berbagai media. Semakin berkembangnya teknologi yang ada di jaman sekarang, membuat masyarakat menjadi mudah dan cepat untuk mendapatkan sesuatu yang dicari, apalagi bagi pelaku bisnis hal tersebut sangatlah penting dan sudah tidak ada lagi penghambat bagi mereka untuk melakukan pemasaran terhadap produk yang dimiliki. Dalam penelitian pemasaran ini, interaksi simbolik dan komunikasi menjadi saling berkaitan sehingga satu dengan yang lainnya harus saling bekerja sama untuk memperlancar komunikasi pemasaran. Penelitian ini menggunakan teori interaksi simbolik dan konsep komunikasi pemasaran. Pendekatan yang digunakan pada penelitian ini adalah penelitian kualitatif dengan strategi studi kasus. Pengumpulan data dilakukan dengan teknik wawancara mendalam, dokumentasi dan observasi langsung. Dalam penelitian ini terjadi interaksi interaksi dalam produk pemasaran longtang, karena adanya interaksi dan perencanaan komunikasi pemasaran yang mampu mengjangkau konsumen untuk membeli.
\end{abstract}

Kata kunci: interaksi simbolik, media sosial, perencanaan komunikasi pemasaran

\section{Pendahuluan}

Jumlah kewirausahaan terus meningkat. Dalam kewirausahaan, seorang pelaku bisnis harus memiliki inovasi dan kreativitas dalam membuat dan 
menciptakan produk yang unik yang bertujuan menjadikannya berbeda dengan yang lainnya. Semakin berkembangnya zaman, usaha makanan dan minuman semakin diminati oleh masyarakat terutama anak muda. Hal ini telah meningkatkan persaingan antara satu usaha kuliner dengan usaha kuliner lainnya. Oleh karena itu seorang wirausaha harus terus berinovasi dengan hal-hal yang update dan terbaru dan memiliki pikiran yang kreatif dalam mengembangkan usahanya, selain itu pelaku bisnis juga harus mencari tahu bagaimana cara memperkenalkan agar produk diketahui oleh masyarakat (Pramelani, 2020).

Pada saat ini, pandemik telah memberikan dampak pada pertumbuhan bisnis makanan dan minuman. Karena Covid-19 hampir sebagian besar mall harus tutup selama beberapa bulan. Hal ini dapat dikatakan sebagai penyebab menurunnya penjualan yang sangat drastis terhadap sebuah usaha.

Menurunnya penjualan yang sangat drastis membuat sebuah usaha mengalami kerugian yang sangat besar, maka dari itu pelaku bisnis harus mencari tahu bagaimana cara untuk menghadapi hal tersebut dan menetapkan perencanaan komunikasi pemasaran terhadap produknya pada saat masa pandemi ini. Pelaku bisnis harus memiliki perencanaan terhadap sebuah pemasaran yang dilakukan agar sebuah usaha dapat terus berjalan dan dapat mencapai tujuan yang diinginkan dalam memasarkan suatu produk yang dimiliki (Sisyadi, 2020).

Komunikasi pemasaran merupakan kegiatan menyampaikan informasi mengenai suatu produk yang tertuju kepada target. Perencanaan komunikasi pemasaran tidak terlepas dari adanya komunikasi antara komunikan dalam tujuan untuk membangun dan adanya interaksi satu dengan yang lain. Komunikasi pemasaran dapat dilakukan dalam berbagai media. Semakin berkembangnya teknologi membuat sudah tidak ada lagi penghambat bagi pelaku bisnis untuk melakukan pemasaran produk yang dimilikinya kepada masyarakat. Media sosial memiliki peran yang sangat besar yaitu sebagai tempat untuk meningkatkan kinerja usaha-usaha dalam memasarkan produknya (Mardiana, 2013).

Dalam penelitian ini, interaksi simbolik dan komunikasi pemasaran menjadi saling berkaitan satu sama lain sehingga satu dengan yang lainnya harus dapat saling bekerja sama untuk memperlancar komunikasi pemasaran dan perencanaan komunikasi pemasaran yang dilakukan dapat berjalan dengan lancar. Berdasarkan latar belakang yang telah dijelaskan, maka peneliti ingin meneliti dan menelusuri lebih dalam lagi mengenai "Bagaimana Peran Interaksi Simbolik dalam Perencanaan Komunikasi Pemasaran pada kedai minuman LongTang?"

\section{Metode Penelitian}

Adanya penelitian ini dilakukan oleh peneliti untuk mengetahui bagaimana peran interaksi simbolik dalam perencanaan komunikasi pemasaran pada kedai minuman Longtang. Metode penelitian yang digunakan adalah penelitian kualitatif dan strategi studi kasus. Menurut Mulyadi (2011) penelitian kualitatif merupakan penelitian yang mencari informasi secara luas dan mendalam. Penelitian kualitatif dapat dilakukan dengan melakukan wawancara yang mendalam dan melakukan observasi langsung ke lapangan penelitian dan datanya dikaji dengan cara nonstatistik. Menurut Yin (2019) mengemukakan bahwa studi kasus merupakan strategi penelitian yang paling tepat untuk penelitian yang mencari tahu dengan "bagaimana" dan "mengapa". 
Subjek dalam penelitian ini yaitu informan atau narasumber yang akan memberikan informasi mengenai penelitian yang akan diteliti. Informan atau narasumber dalam penelitian ini yaitu general manager Longtang, supervisor dan barista. Objek dalam penelitian ini yaitu kedai minuman Longtang yang berada di Pluit Village Mall Jakarta Utara. Metode pengumpulan data dalam penelitian ini yaitu wawancara mendalam terhadap narasumber, melakukan observasi langsung dan dokumentasi. Menurut Yin (2019) wawancara mendalam merupakan sumber informasi yang mendalam yang diberikan oleh para narasumber dengan tujuan untuk menemukan dan mendapatkan permasalahan yang sedang diteliti oleh peneliti. Dalam penelitian ini peneliti melakukan wawancara mendalam dengan 3 narasumber atau informan minuman Longtang. Observasi langsung merupakan observasi yang dilakukan oleh peneliti dengan cara melakukan observasi langsung ke lapangan (Yin, 2019). Dokumentasi adalah jenis informasi yang didapatkan dalam berbagai bentuk seperti foto, video, rekaman atau tulisan (Yin, 2019).

\section{Hasil Temuan dan Diskusi}

Berdasarkan temuan penelitian yang peneliti lakukan dengan observasi langsung pada kedai minuman Longtang dan wawancara mendalam dengan narasumber, peneliti menemukan:

\section{Interaksi simbolik dalam perencanaan komunikasi pemasaran minuman Longtang}

George Herbert Mead menjabarkan tiga konsep pemikiran dasar yang penting dalam teori interaksi simbolik yaitu Pikiran (Mind), Diri (Self) dan Masyarakat (Society) (West dan Turner, 2012).

Pikiran (thought) adalah interaksi atau komunikasi yang dilakukan dengan yang lainnya dan komunikasi di dalam diri manusia tanpa tekanan sosial (West dan Turner, 2012). Dari temuan peneliti, interaksi dalam komunikasi antara karyawan Longtang menggunakan bahasa indonesia, sedangkan bahasa yang digunakan owner dan General Manager menggunakan bahasa mandarin. Selain itu, untuk mengetahui sifat masing-masing anggota Longtang dilihat dari pada saat melakukan interview. Mead mengatakan pikiran dapat dikembangkan dengan adanya interaksi antara individu dengan yang lainnya (West dan Turner, 2012). Pada saat awal Longtang mulai beroperasi, pernah terjadinya miss communication antara karyawan dalam Longtang, dengan berjalannya waktu dan adanya interaksi yang terjadi antara karyawan/i Longtang maka terbentuknya kesamaan makna sosial. Hal tersebut sejalan dengan teori yang dikemukakan oleh Mead.

Joel M Charon mengatakan bahwa terbentuknya masyarakat karena adanya nilai dan aturan yang dilaksanakan, ditaati, dan telah disepakati oleh bersama (Pribadi, Suganda, Venus dan Susanto, 2018). Masyarakat terbentuk menjadi dua bagian yaitu Orang Lain Secara Khusus (particular others) dan orang Lain secara umum (generalized others) (West dan Turner, 2012). Pada penelitian ini, adanya nilai dan peraturan (generalized others) dalam Longtang yang harus ditaati seperti dalam menjaga kualitas minuman Longtang terdapat beberapa SOP yang harus dijalankan oleh karyawan Longtang, seperti SOP karyawan, SOP dalam pembuatan minuman, SOP dalam preparation.

Di tengah pandemi covid 19 yang terjadi, terdapat peraturan tambahan yang harus ditaati oleh karyawan/i Longtang harus memakai perlengkapan untuk menjaga 
kebersihan seperti appron, topi, face shield, masker, sarung tangan, hand sanitizer. Perlengkapan tersebut harus dipakai selama karyawan masih berada dalam store. Peraturan yang telah ditetapkan dalam Longtang harus ditaati dan akan ada sanksi yang diberikan bagi yang melanggar peraturan tersebut. Dari temuan peneliti, owner Longtang menganggap general manager merupakan orang kepercayaan (particular others). Owner Longtang memberikan kepercayaan untuk mengelola Longtang kepada general manager.

Mead mengemukakan bahwa diri (self) adalah manusia dapat melihat dirinya sendiri berdasarkan pandangan atau penilaian dari orang lain (West dan Turner, 2012). Dari penelitian ini ditemukan bahwa dalam General Manager merasa nyaman menjadi diri sendiri di lingkungan kerjanya. Selain itu, tidak ada penilaian khusus maupun perbedaan perlakuan terhadap karyawan LongTang. Dalam melaksanakan pekerjaannya, karyawan Longtang saling bekerja sama dan tidak membedakan satu sama lainnya. Karyawan juga saling membantu dan melengkapi satu sama lain.

\section{Perencanaan Komunikasi Pemasaran Kedai Minuman LongTang}

Komunikasi pemasaran adalah suatu kegiatan komunikasi yang dilakukan yang bertujuan untuk mencapai target sasaran yang telah ditentukan. Adanya komunikasi pemasaran yaitu untuk menciptakan dan mencapai tujuan komunikasi yang tepat. Perencanaan komunikasi pemasaran terdiri dari tujuan bisnis, strategi, taktis, implementasi, monitoring dan evaluasi (Pribadi, Suganda, Venus dan Susanto, 2018). Dari temuan penelitian, peneliti menemukan 6 (enam) perencanaan komunikasi pemasaran dalam Longtang yang sejalan dengan teori yaitu:

a. Tujuan Bisnis

Tujuan bisnis sebuah perusahaan adalah menghasilkan dan menciptakan keuntungan yang sebesar-besarnya. Dari temuan peneliti, tujuan bisnis LongTAng sesuai dengan teori perencanaan komunikasi pemasaran yakni mendapatkan income dan ingin mengulang jejak sukses minuman asli China tersebut di Indonesia.

b. Strategi

Strategi adalah susunan perencanaan yang ada untuk mencapai sebuah tujuan. Pada penelitian ini, strategi yang digunakan Longtang dalam komunikasi pemasaran pada kedai minuman LongTang saling berhubungan dengan adanya tujuan komunikasi, saluran komunikasi, target market, kompetitor dan tema komunikasi.

c. Taktis

Taktis merupakan sebuah tindakan yang dilakukan sesuai dengan strategi yang telah disusun dalam sebuah perencanaan komunikasi pemasaran. Adanya pandemi Covid-19, Longtang melakukan promosi melalui media sosial dan melalui Grabfood dan memberikan promo potongan ongkos kirim dan Longtang terus meningkatkan dalam membangun hubungan yang baik dengan konsumen.

d. Implementasi

Implementasi adalah sebuah hasil atau keputusan yang dilakukan berdasarkan perencanaan yang ada dan telah tetapkan. Dari temuan peneliti, dalam mengawasi penjualan dan memastikan proses pemasaran yang dilakukan LongTang berjalan dengan lancar yaitu dengan cara melihat hasil atau report yang telah dibuat oleh karyawan per-tanggalnya.

e. Monitoring

Monitoring merupakan sebuah kegiatan pengawasan terhadap pencapaian apakah sudah sesuai dengan yang telah diinginkan. Pada penelitian ini, LongTang memantau kinerja para pekerja dalam melayani konsumen. Beberapa hal yang masuk 
dalam proses monitoring yaitu memperhatikan SOP telah dijalankan sesuai yang direncanakan atau tidak, LongTang juga memiliki General Manager yang juga dibantu oleh seorang supervisor (pemimpin store) dalam memonitor kinerja pekerja dan hal-hal lainnya.

\section{f. Evaluasi}

Evaluasi adalah sebuah kegiatan untuk melihat dan mengoreksi suatu kekurangan agar kedepannya dapat diperbaiki dan menjadi lebih baik. Dalam melakukan evaluasi, Longtang memiliki hambatan dari proses pemasaran Longtang adalah banyaknya brand minuman lainnya yang membuat masyarakat berpikir bahwa semua minuman tersebut memiliki rasa yang sama. Untuk mengatasi hambatanhambatan yang ada, maka LongTang terus mencari tahu cara atau ide untuk mempromosikan dan memasarkan produk LongTang.

\section{Simpulan}

Berdasarkan penelitian yang telah dilakukan oleh peneliti terhadap peran interaksi simbolik dalam perencanaan komunikasi pemasaran kedai minuman Longtang. Peran dari interaksi simbolik dalam LongTang memberikan hasil yang cukup baik dan berperan sangat penting dalam proses terbentuknya perencanaan komunikasi pemasaran. Interaksi simbolik dalam LongTang mempunyai peran yang sangat penting dan memberikan hasil yang baik antara sesama kelompok dapat bekerja sama dengan kompak dan juga terhadap para konsumen sehingga menciptakan dan membangun hubungan yang baik secara internal maupun eksternal.

Longtang memiliki 6 (enam) perencanaan komunikasi pemasaran yang bertujuan untuk dapat memasarkan produknya dengan baik kepada target yaitu dengan adanya tujuan bisnis, strategi, taktis, implementasi, evalusi dan monitoring. Dalam Longtang adanya peraturan yang harus ditaati, hal ini sesuai dengan teori generalized others yang dikemukakan oleh Mead. Pada masa pandemi ini, Longtang melakukan pemasaran melalui media sosial. Selain itu, Longtang juga memberikan banyak promo yang menarik dan potongan ongkos kirim dan juga longtang memiliki kemasan botol yang unik untuk dihidangkan oleh para konsumennya.

\section{Ucapan Terima Kasih}

Penulis mengucapkan terima kasih kepada pihak Fakultas Ilmu Komunikasi Universitas Tarumanagara. Terima kasih kepada informan atau narasumber yang telah bersedia memberikan informasi bagi penelitian ini.

\section{Daftar Pustaka}

Mardiana, S. (2013). Peranan Komunikasi Pemasaran Dalam Membentuk Perilaku Konsumen. Jurnal Komunikasi, 2 (2) , 40-46.

Mulyadi, M. (2011). Penelitian Kuantitatif dan Kualitatif Serta Pemikiran Dasar Menggabungkannya. Jurnal Komunikasi dan Media, 15(1), 127-138.

Pramelani. (2020). Faktor Ketertarikan Minuman Kopi Kekinian Terhadap Minat Beli Konsumen Kalangan Muda. Jurnal Ilmiah Manajemen, 15(1), 121-129.

Pribadi, M. A., Suganda, V., \& Susanto, E. H. (2018). Dinamika Perusahaan Periklanan Indonesia: Studi Kasus Komunikasi dan Budaya Organisasi Dwi Sapta IMC dan Fortune Indonesia. Disertasi Universitas Padjajaran. 
Sisyadi, B. (2019). Interaksi Simbolik Sebagai Pembentukan Perencanaan Komunikasi Pemasaran (Studi Etnografi Komunikasi Pada PT. INTI OZZIGENO NARA SOLUSI). Jurnal Komunikasi.

West, R., \& Turner, L. H. (2012). Pengantar Teori Komunikasi Analisis dan Aplikasi. Jakarta: Salemba Humanika.

Yin, R. K. (2019). Studi Kasus Desain\&Metode. Depok: PT Raja Grafindo Persada.https://katadata.co.id/ameidyonasution/berita/5f057c4ca497e/dampak -pandemi-pertumbuhan-industri-makanan-minuman-tak-capai-target diakses pada tanggal 13 September 2020 